\title{
Physiological Identification, Morphological Analysis, and Development of Identified Serotonin-Proctolin Containing Neurons in the Lobster Ventral Nerve Cord
}

\author{
Barbara S. Beltz and Edward A. Kravitz \\ Department of Neurobiology, Harvard Medical School, Boston, Massachusetts 02115
}

\begin{abstract}
Amines and peptides exert a wide range of physiological actions on both central neurons and peripheral tissues. Among these actions, serotonin and octopamine are known to trigger contrasting postures when injected into freely moving lobsters. Immunocytochemical studies of lobster ganglia have identified presumptive serotonergic neurons, their central and peripheral projections, and their terminal fields of arborization. More than 100 neurons that show serotonin-like immunoreactivity have been found in the lobster nervous system (Beltz and Kravitz, 1983). From immunocytochemical studies it appears that varicosities within peripheral neurosecretory structures and endings in certain central neuropil regions arise from the same 2 pairs of large cells located in the fifth thoracic (T5) and first abdominal (A1) ganglia. Because we believed that such cells could account for the central and peripheral actions of serotonin on the postural system, we chose to study these 2 pairs of neurons in greater detail. In the previous paper, Siwicki et al. (1987) report that these neurons contain the pentapeptide proctolin in addition to serotonin. In this communication, we report that (1) these cells can be Identified reliably in living preparations; (2) they have large fields of innervation projecting anteriorly into at least 4 segmental ganglia; (3) these neurons are the origin of the fibers that form the thoracic second root neurosecretory regions; (4) they are generally spontaneously active neurons that have overshooting action potentials in their cell bodies; and (5) the serotonin and proctolin immunoreactivities are first expressed in these cells at widely different times in development.
\end{abstract}

Amines and peptides are believed to play vital roles in regulating or controlling aspects of the hehavioral repertoire of animals. This is particularly well documented in invertebrates where, for example, eclosion hormone triggers larval and pupal ecdysis behavior in silkmoths and hawkmoths (Reynolds and Truman, 1983; Truman and Weeks, 1985); serotonin can elicit swimming and feeding behavior in leeches (Willard, 1981; Kristan and Nusbaum, 1983; Kristan and Weeks, 1983; Lent and Dickinson, 1984); egg-laying hormone induces a complex pattern of behaviors associated with egg-laying in Aplysia (Kupfermann, 1967;

Received May 12, 1986; revised Aug. 5, 1986; accepted Aug. 8, 1986.

We wish to thank S. Hansen and J. Gagliardi for technical assistance, and D. Cox for secretarial support. This work was supported by NIH Grants MH-40321 to B.S.B. and NS-07848 to E.A.K.

Correspondence should be addressed to Dr. Edward A. Kravitz, Department of Neurobiology, Harvard Medical School, 25 Shattuck Street, Buston, MA 02115 Copyright $\odot 1987$ Society for Neuroscience $0270-6474 / 87 / 020533-14 \$ 02.00 / 0$
Strumwasser, 1983; Mayeri and Rothman, 1985); and proctolin, FMRFamide, FMRFamide homologs, serotonin, octopamine, and dopamine regulate cardiac, stomatogastric, and neuromuscular function in mollusks, crustaceans, and annelids (Lingle, 1981; Hooper and Marder, 1984, 1985; Kuramoto and Ebara, 1984; O'Donohue et al., 1984; Kravitz et al., 1985; Kuhlman et al., 1985a, b; Flamm and Harris-Warrick, 1986a, b).

Serotonin and octopamine trigger opposing effects when injected into the circulation of freely moving lobsters or crayfish. Serotonin produces a sustained flexion of the limbs and abdomen, resulting in an "aggressive-looking" stance; octopamine produces a sustained extension, a "submissive-looking" posture (Livingstone et al., 1980). We believe that the amines modulate the opposing motor patterns by coordinated actions at 2 separate sites (Harris-Warrick and Kravitz, 1984; Harris-Warrick, 1985). First, they act as neurohormones released from neurosecretory regions into the hemolymph, where, at very low concentrations, they prime peripheral exoskeletal muscles to respond more vigorously. No opposition is seen, however, in the direct actions of amines on flexor or extensor muscles (Livingstone et al., 1980). The specificity lies at the second site of action, within the ventral nerve cord, where octopamine and serotonin activate opposing motor programs involved in coordinating extension and flexion (Livingstone et al., 1980; Harris-Warrick and Kravitz, 1984). The central actions require much higher concentrations of amines than the peripheral actions, concentrations that are orders of magnitude higher than the circulating levels. To attain such high levels, we suspect that amines must be released from endings near their central target sites. As the next stage in this analysis, we have begun to search for endogenous aminecontaining neurons that might supply 2 separate sets of endings (1) to peripheral neurosecretory regions for actions on peripheral targets, and (2) to central neuropil regions for actions on central motor-pattern-generating neurons.

First, we used immunocytochemical procedures to locate cells, processes, and endings in the lobster nervous system that were immunoreactive for serotonin (Beltz and Kravitz, 1983). These studies revealed more than 100 immunoreactive neurons located primarily in central ganglia. Serotonin-immunoreactive varicosities were found in central neuropil regions and in 2 peripheral neurosecretory structures, the pericardial organs and the proximal regions of the thoracic second roots. From the immunocytochemical studies, it appeared that varicosities within the peripheral neurosecretory structures and endings in certain central neuropil regions might arise from the same cells: These were 2 pairs of large neurons, with their somata located in the fifth thoracic (T5) and first abdominal (A1) ganglia. To 


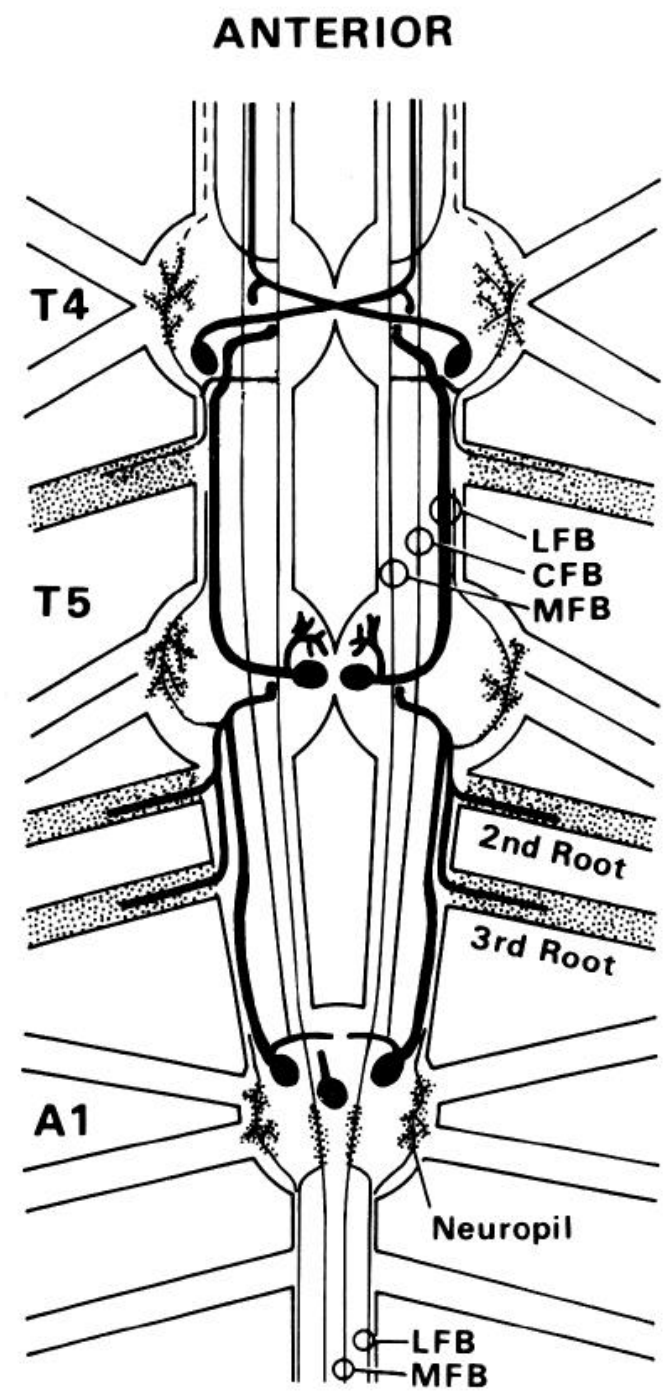

POSTERIOR

Figure 1. Schematic diagram of the serotonin-immunoreactive cell bodies, fibers, and neuropil of a part of the ventral nerve cord. $T 4$, fourth thoracic ganglion; $T 5$, fifth thoracic ganglion; $A 1$, first abdominal ganglion. Composite drawing of whole mount preparations of 10 ventral nerve cords. Cell bodies are drawn as large, filled, round, or elongate circles. Heavy black lines represent immunoreactive fibers that have been traced to their cell bodies of origin. Fine lines indicate immunoreactive fibers that have not been connected with cell bodies. Each of the fine lines of the lateral fiber bundles $(L F B)$, central fiber bundles $(C F B)$, and midline fiber bundles $(M F B)$ represents several fibers. Dashed lines indicate fibers that have not been directly visualized in these immunocytochemical preparations, but that we believe exist because the patterns of staining are similar from ganglion to ganglion. Stippled regions represent fine processes and varicosities of neuropil and neurohormonal release regions. [For further details, see Beltz and Kravitz (1983) from which this figure has been reprinted, in a slightly modified form, with permission.]
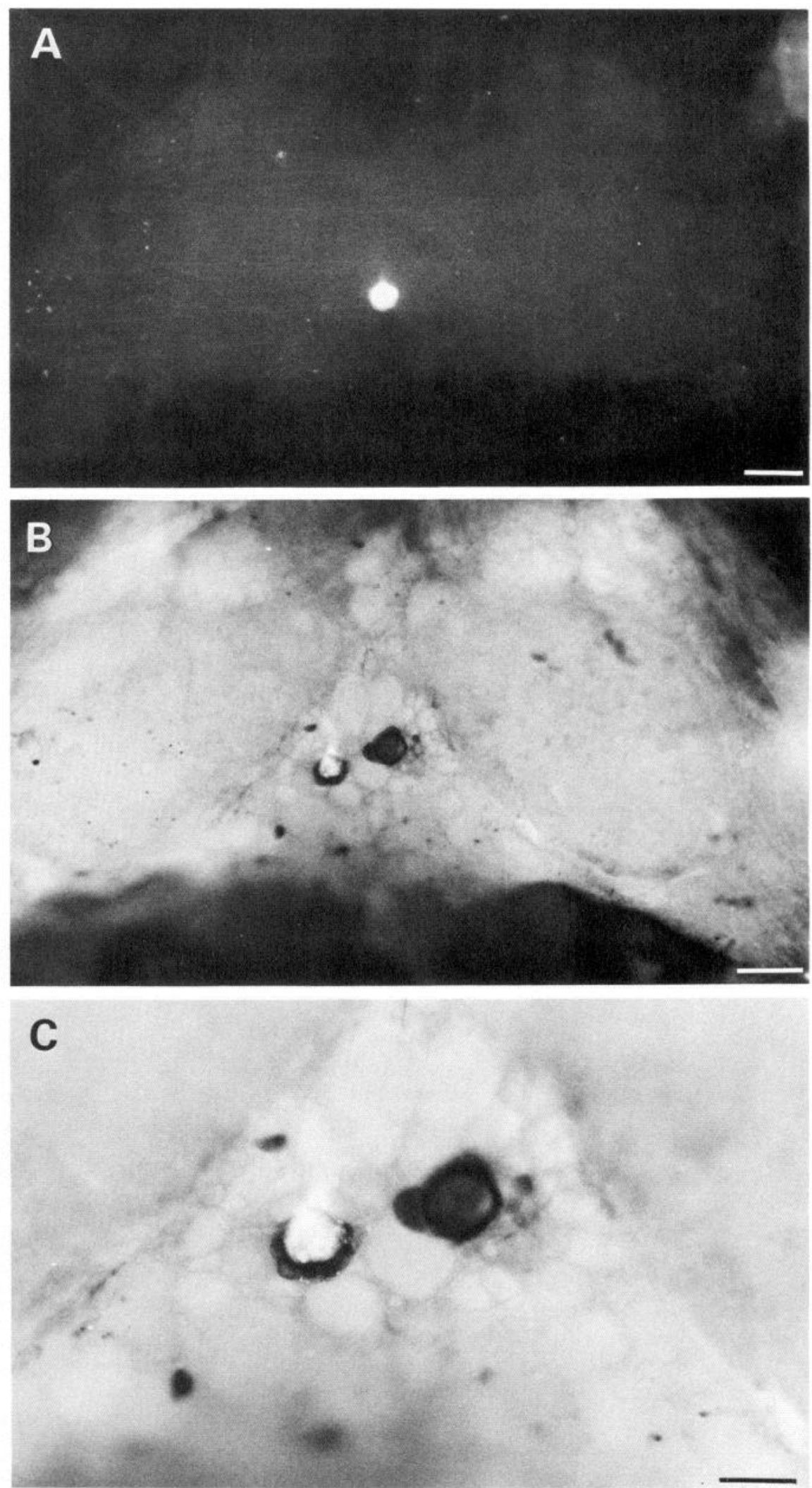

Figure 2. A, Lucifer yellow-injected cell in an unfixed fifth thoracic ganglion (T5) that fulfilled the positional, size, and physiological criteria outlined in the text. The outlines of the ganglion are faintly visible. Scale bar, $200 \mu \mathrm{m}$. $B$ and $C$, Following Lucifer yellow injection, the preparation shown in $A$ was fixed and processed for serotonin immunocytochemistry using a peroxidase-labeled secondary antibody. This procedure labels the paired neurons in T5 with a dark brown HRP precipitate. The left cell of the pair has been doublelabeled using the Lucifer yellow-serotonin immunocytochemical technique. A higher magnification of the 2 T5 cells is shown in $C$. Scale bars: $B, 200 \mu \mathrm{m} ; C, 100 \mu \mathrm{m}$. 
study these neurons further and to explore whether they might be involved in postural regulation, we have (1) defined physiological criteria that can be used to identify the cells in living preparations; (2) carried out anatomical studies using injections of horseradish peroxidase (HRP) to determine the detailed projections of the cells and to identify their possible targets; and (3) examined some electrophysiological properties of these neurons. The T5 and A1 paired cells contain the pentapeptide proctolin in addition to serotonin (Siwicki et al., 1987). These cells, therefore, provide further opportunities to study the physiological actions of single identified amine- and peptide-containing neurons and to explore the developmental expression of their serotonin and proctolin phenotypes. Data also are presented showing a wide time difference in the development of serotonin and proctolin immunoreactivities in these cells during the embryonic and larval life of lobsters.

\section{Materials and Methods}

\section{Physiological identification of T5 and AI serotonin- proctolin-containing neurons}

Lucifer yellow injection. Adult lobsters $(0.5 \mathrm{~kg})$ were purchased locally and maintained in 125 gallon tanks in artificial seawater at $10-14^{\circ} \mathrm{C}$. Ventral nerve cords were dissected in cold lobster saline of the following composition: $462 \mathrm{~mm} \mathrm{NaCl}, 16 \mathrm{~mm} \mathrm{KCl}, 26 \mathrm{~mm} \mathrm{CaCl}_{2}, 8 \mathrm{~mm} \mathrm{MgCl}_{2}$, $11 \mathrm{~mm}$ glucose, $10 \mathrm{~mm}$ Tris, $10 \mathrm{~mm}$ maleic acid, adjusted to $\mathrm{pH} 7.4$ (Otsuka et al., 1967; Evans et al., 1976). T5 and Al ganglia were pinned ventral side up in a Sylgard- (Dow Corning) coated petri dish, desheathed, and viewed with dark-field optics while being continuously perfused with cold $\left(6-10^{\circ} \mathrm{C}\right)$ oxygenated saline. Lucifer yellow (LY; Stewart, 1978) was iontophoresed into neurons that fulfilled the following criteria: (1) They were approximately the same size as, and in the general location of, the paired cells labeled for serotonin and proctolin using immunocytochemical methods (Beltz and Kravitz, 1983; Siwicki and Bishop, 1986); and (2) action potentials could be elicited by extracellular stimulation of the ipsilateral connective 2 segments anterior to the cell body (see Results for rationale). LY electrodes were prepared by backfilling the tips of capillary electrodes with 3-5\% LY in distilled water; the shanks of the electrodes were filled with $1 \mathrm{M}$ lithium chloride. Iontophoresis of LY was accomplished by passing 5-20 nA of hyperpolarizing current in $500 \mathrm{msec}$ pulses at $1 \mathrm{~Hz}$ for $1-3 \mathrm{hr}$ (adapted from Stewart, 1978). LY was visualized in living cells by placing a blue filter (BG 12 or equivalent) over the incandescent light source. Following 1$48 \mathrm{hr}$ at $4^{\circ} \mathrm{C}$, to allow for diffusion of the dye, preparations were viewed and photographed with a Zeiss ICM 405 photoinvertoscope using epifluorescent excitation. Exciter-barrier filter and reflector combination cubes were used, which contained excitation at $365 \mathrm{~nm}$, a reflector at $395 \mathrm{~nm}$, and a long-pass barrier filter at $420 \mathrm{~nm}$. After photography, preparations were fixed for $12-36 \mathrm{hr}$ in $4 \%$ paraformaldehyde in $0.2 \mathrm{M}$ cacodylate buffer with $462 \mathrm{mM} \mathrm{NaCl}$ and $16 \mathrm{mM} \mathrm{KCl}$ added.

Immunocytochemistry. The fixed tissues were rinsed in several changes of $0.1 \mathrm{M}$ phosphate buffer (PB; $\mathrm{pH} 7.4$ ) containing $0.3 \%$ Triton X-100 and $0.1 \%$ sodium azide (PTA) over a period of 6-8 hr. A 1:200 dilution of anti-serotonin antiserum (ImmunoNuclear) was added and the tissues were incubated at $4^{\circ} \mathrm{C}$ for $15-20 \mathrm{hr}$ (Beltz and Kravitz, 1983). Following primary antibody treatment, the tissues were rinsed in PTA for $6-8 \mathrm{hr}$, then incubated for $15-20 \mathrm{hr}$ at $4^{\circ} \mathrm{C}$ with labeled secondary antibody, an affinity-isolated goat anti-rabbit IgG conjugated to HRP (Boehringer Mannheim) used at a 1:20 dilution. The excess of secondary antibody was removed by repeated rinsing over $2-3 \mathrm{hr}$ in PB. The samples were then incubated for 30-60 min with 3',3-diaminobenzidine tetrahydrochloride (DAB; Sigma) $(0.02-0.05 \%$ in PB), and reacted with $0.02 \%$ $0.05 \%$ DAB in PB containing $0.001-0.005 \%$ hydrogen peroxide. Development of the HRP reaction product was observed microscopically, and usually stopped within $15-45 \mathrm{~min}$ with several rinses of PB. The preparations were dehydrated with increasing concentrations of ethanol, cleared in toluene, and mounted in Diatex (Scientific Products, M7638).

The use of a directly labeled secondary antibody proved superior to peroxidase-antiperoxidase or avidin-biotin methods because a weaker signal was obtained, which was less likely to block the LY fluorescent signal. If too dense, the HRP reaction product tended to quench the LY signal. On the other hand, if the LY signal was too strong, there was interference with the immunoreactive staining and the HRP signal was difficult to see (see Fig. 2,b,c). In practice, the amount of LY injected, antibody concentrations, and HRP development time had to be titrated carefully to achieve an optimal double stain.

\section{HRP anterograde injection protocol}

HRP was pressure-injected into physiologically identified T5 and A1 serotonin-proctolin cells in ganglia from juvenile lobsters (1-2 in. carapace length). The technical details of the protocol were elaborated with the advice and consultation of Dr. R. Calabrese, whose generous help we acknowledge. The tips of capillary electrodes were backfilled with a $2-5 \%$ solution of HRP in $0.2 \mathrm{M} \mathrm{KCl}$ containing $0.2 \%$ fast green. Electrode shanks were filled with a conducting solution of $0.2 \mathrm{M} \mathrm{KCl}$. Filled electrodes were beveled using a motor-driven rotary platform beveler, the surface of which was covered with a $0.3 \mu \mathrm{m}$ alumina abrasive film paper (6775, E54; Arthur Thomas Co.). The electrode was mounted on a micromanipulator and gently lowered to touch the paper until the shadow of the electrode on the platform was slightly arched. Electrodes were beveled for 20-40 sec; electrode resistance was generally 5-20 M $\Omega$ after beveling. HRP was ejected from the electrode with $0.5-3 \mathrm{sec}$ pulses of pressure (1-20 psi). Injection times varied depending upon the appearance of the cells and the stability of the resting potential. Under optimal conditions, injections were continued until cells were a deep blue color. Swelling of cells was minimized by injecting slowly over long times (2$6 \mathrm{hr}$ ) and by carefully controlling pressure. After injection, preparations were rinsed in fresh saline and HRP was allowed to diffuse at $4^{\circ} \mathrm{C}$ for $12-72 \mathrm{hr}$. During this time tissues were placed in L-15 medium (Gibco) with added gentamycin $(100 \mathrm{U} / \mathrm{ml})$, and with salts adjusted to be isoosmotic with lobster saline. Preparations were fixed with $2 \%$ paraformaldehyde, $0.3 \%$ glutaraldehyde in $\mathrm{PB}$ for 30-90 min. After rinsing in several changes of $P B$, tissues were reacted with $D A B$ as outlined above (see Immunocytochemistry), except that the optimal development time was usually in the range of 30-120 min. Formation of the DAB reaction product was stopped by several rinses in PB and preparations were dehydrated in an increasing ethanol series and cleared in xylene. Ganglia were mounted between 2 coverslips with Permount, viewed, and drawn with the computer reconstruction system described below.

\section{Physiological studies}

Once the T5 and A1 neurons could be reliably identified on the basis of the above protocol, the physiological properties of the cells were examined using conventional intracellular recording techniques (Otsuka et al., 1967). Synaptic activity and action potentials were recorded on a chart recorder and on magnetic tape for later analysis by computer.

\section{Developmental studies}

Eggs and larval lobsters were obtained from the Massachusetts State Lobster Hatchery on Martha's Vineyard, MA, from the Marine Biological Laboratory at Woods Hole, MA, or from the New England Aquarium in Boston, MA.

Embryos were staged by measuring the size of their eyes (Herrick, 1896; Perkins, 1972). While the embryo was in the egg, eye measurements were made to the nearest micron with an ocular micrometer in a dissecting microscope at a magnification of $25 \times$. The greatest widths and lengths were taken and averaged. The resulting figure was used as an index of development. The index of the eye is about $70 \mu \mathrm{m}$ when pigment is first measurable, and about $560 \mu \mathrm{m}$ at hatching (Perkins, 1972).

Staging of larvae is accomplished by microscopic examination of the anatomy of individual animals and a comparison with the detailed descriptions available for each larval stage (Herrick, 1896).

Nerve cords from embryonic and larval lobsters were processed for immunocytochemistry for serotonin and proctolin by identical protocols. Embryonic or larval lobsters were pinned to a Sylgard-coated dish and the ventral nerve cord was exposed by partial dissection. Tissues were fixed overnight at $4^{\circ} \mathrm{C}$ in $4 \%$ paraformaldehyde in PB containing $\mathrm{NaCl}(462 \mathrm{mM})$ and $\mathrm{KCl}(16 \mathrm{~mm})$ (PBS). After rinsing out the fixative with PBS, further dissection was performed. In some cases, the entire nerve cord was freed from the animal at this point; in other cases, small amounts of exoskeleton were left to assist in pinning out of the nerve cord. Micropins were used to hold the tissue to the Sylgard surface and a small platform containing the nerve cord was cut from the Sylgard dish. Throughout the subsequent processing, the Sylgard platform was 
A
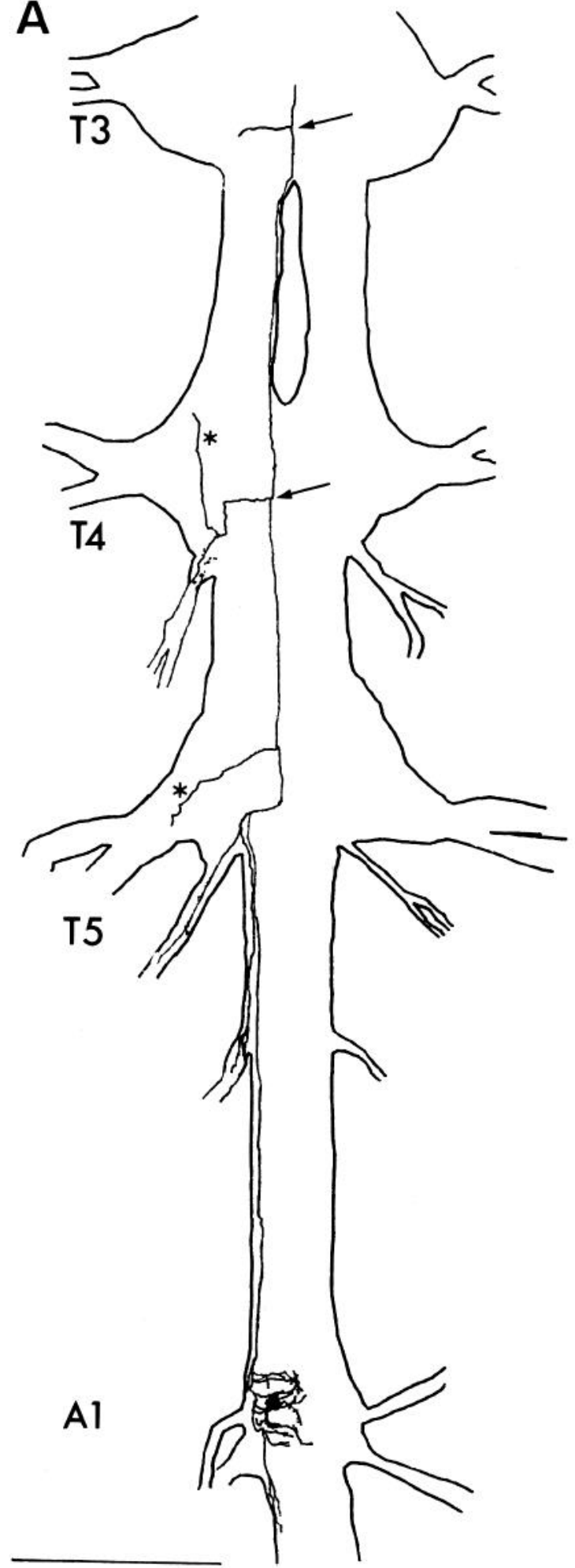

B
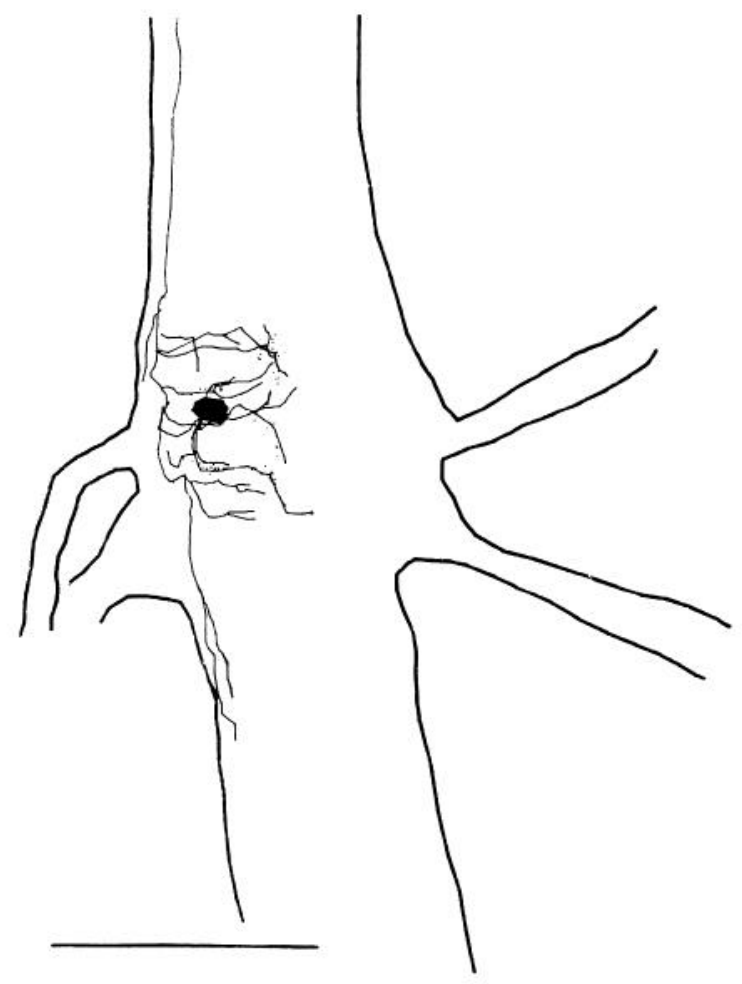

C

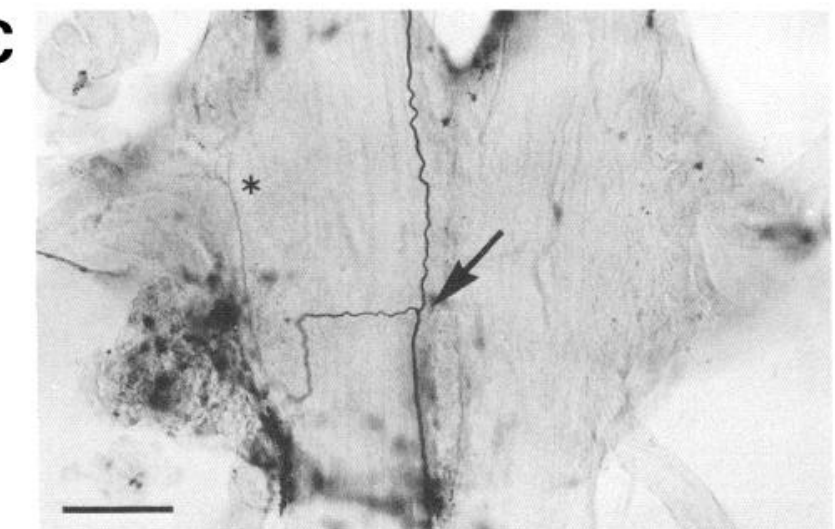

D

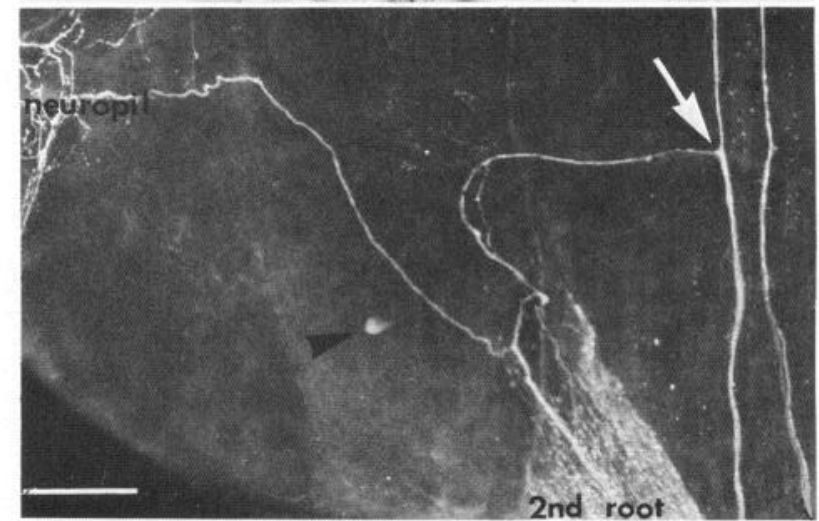

Figure 3. HRP injection of the left $A 1$ serotonin-proctolin neuron, and comparison of its branching pattern with fibers stained by serotonin immunocytochemistry. $A$, Computer reconstruction of an HRP-injected left $A 1$ serotonin-immunoreactive cell. The projection of the $A 1$ cell is shown in the third (T3), fourth (T4), and fifth (T5) thoracic ganglia and first abdominal ganglion (AI). Note that the $A 1$ cell forms a right-angle branch in $T 3$ and T4 (arrows). This branching pattern has also been seen in the second thoracic ganglion in other injected preparations. This cell is known to form a lateral neuropil in each of these ganglia, as seen in $T 4$ and $T 5$ (asterisks). A branch of the $A 1$ cell also projects out the ipsilateral thoracic second root of $T 2-T 5$ and forms varicose release sites in the sheath of the second roots (shown here for $T 4$ and $T 5$ ). Scale bar, $1 \mathrm{~mm}$. B, First abdominal ganglion of $A$ is enlarged here, showing the main trunk, fine fibers, and varicosities in the cell-body region. Scale bar, $500 \mu \mathrm{m}$. $C$, Photograph of the fourth thoracic ganglion from the preparation in $A$ showing the HRP-filled projection of the left $A 1$ serotonin-proctolin neuron. 
transferred through a series of $1 \mathrm{ml}$ test tubes containing the wash solutions. The following steps were performed: (1) Rinse in $0.1 \mathrm{M}$ phosphate buffer, $0.3 \%$ Triton X-100 (PT) for 4-6 hr; (2) incubate in primary antibody (anti-serotonin, 1:200 in PT; anti-proctolin, 1:300 in PT) for $12-20 \mathrm{hr}$ at $4^{\circ} \mathrm{C}$; (3) rinse in PT for 6-12 hr; (4) incubate in biotinylated goat anti-rabbit IgG (Vector Labs) at a 1:200 dilution in PT for 6-12 $\mathrm{hr}$ at $4^{\circ} \mathrm{C}$; (5) rinse (in PB) for 3-6 hr; (6) incubate in avidin-biotinperoxidase complex (ABC; Vector Labs), 1:100 for $12-20 \mathrm{hr}$ at $4^{\circ} \mathrm{C}$; (7) rinse preparations in PB for $2-4 \mathrm{hr}$; (8) incubate in $0.05 \% \mathrm{DAB}$ and develop by incubating in $0.02-0.05 \%$ DAB in PB with added $0.001-$ $0.005 \% \mathrm{H}_{2} \mathrm{O}_{2} ;(9)$ after $5-30$ min rinse in $\mathrm{PB}$ and dehydrate rapidly in ethanol, unpin from the Sylgard platform, clear in xylene, and mount in Permount. Preparations were viewed and photographed using a Zeiss photomicroscope with Nomarski optics.

\section{Computer reconstructions}

HIRP-injected cells and HRP-labeled immunocytochcmical preparations were drawn using a computer reconstruction system (see Figs. 3, $A, B ; 4, A, D ; 6, B, C ; 7, B, C)$. The hardware used in the reconstruction system was designed by J. J. Capowski (Capowski and Sedivec, 1981) and modified for our purposes. This consisted of a Zeiss compound microscope, fitted with stepping motors which drove its stage in the $X$, $Y$, and Z directions, controlled by a Digital Equipment PDP-11/23 computer. A camera lucida head was fitted to the microscope and directed towards a graphics cathode ray tube (CRT) display generated by a dynamic refreshed vector system (NDP3). This display could be seen through the microscope overlaid upon the biological image. Commands were given to the program by means of a keyboard, joystick, buttons, and a magnetic data pad.

To record data, the viewer used the data tablet to move a cursor on the screen (and thus in the microscope ficld of vicw) and was able to trace objects and instruct the computer to record points and lines in 3 dimensions. The $X$ and $Y$ coordinates were taken from the position of the data pad cursor, while $Z$ was taken as the vertical level of the microscope stage, adjusted by the viewer with a joystick to bring various objects into focus. The 3-dimensional data were reconstructed using mathematical algorithms and dynamically displayed on the CRT, and could be zoomed to magnify different objects and rotated to study their spatial relationships. The output also could be sent to a Hewlett-Packard 7475A felt-tip pen plotter to produce the reconstructions seen in this paper.

\section{Results}

\section{Physiological identification of serotonin-proctolin containing} neurons

Our first task was to establish a protocol that could be used to routinely find and identify the serotonin-proctolin cells in the T5 and A1 ganglia of the ventral nerve cord. Towards this goal we used a double-labeling procedure to test whether we had correctly identified the cells (LY injection followed by immunocytochemical processing for serotonin; see Materials and Methods). Neurons in T5 and A1 were penetrated with microelectrodes and LY was injected into neurons that fulfilled the following criteria: (1) They were found in locations in the ganglia similar to those of cells previously identified by immunocytochemistry (Beltz and Kravitz, 1983); (2) they were approximately the same size as the immunocytochemically labeled cells of the earlier studies; and (3) action potentials could be elicited by extracellular stimulation of the ipsilateral connective 2 segments anterior to the cell body. This stimulation site was selected since the earlier immunocytochemical results suggested that the ipsilateral connective would contain the main axonal projection of the T5 and Al cells, and that the axons might travel forward for at least 2 segments (Fig. 1). Following LY injections (Fig. $2 A$ ), preparations were fixed and processed for serotonin immunocytochemistry using a peroxidase-labeled secondary antibody (see Materials and Methods). Cells that wcrc correctly identified in living preparations were double-labeled with LY and the peroxidase reaction product (Fig. 2, $B$ and $C$ ). Of 8 cells identified in this way ( 4 in $T 5,4$ in A1), all were double-labeled with LY/HRP, indicating that size, position, and physiological criteria could be used to reliably identify the T5 and $\mathrm{Al}$ serotonin-proctolin neurons.

\section{Electrophysiological properties of the T5-A1 neurons}

While identifying the T5 and A1 neurons and characterizing their anatomy (see below), the following physiological properties were observed.

Resting and action potentials. The T5 and A1 serotonin-proctolin neurons had resting potentials between 50 and $80 \mathrm{mV}$ at $6-10^{\circ} \mathrm{C}$. Resting potentials were about $50 \mathrm{mV}$ on penetration of the cells, and gradually improved over the next $30 \mathrm{~min}$. A characteristic feature of the physiology of these cells was thcir large-amplitude action potentials with a prominent undershoot (recorded in the cell body) and their tendency to be spontaneously active. Action potentials recorded in A1 cell bodies ranged in size from 50 to $70 \mathrm{mV}$; T5 cell action potentials could be as large as $60 \mathrm{mV}$, but were generally $20-40 \mathrm{mV}$ in amplitude, even in very stable recordings. Cells fire bursts of action potentials or spontaneous low-frequency spikes for 15-30 min after penetration, and often continued to fire throughout hours of recording. No rigorous experiments have been carried out as yet to test whether the bursting mechanism is endogenous to the cells, but thus far we have seen no evidence that generation of the bursts results from underlying synaptic activity. Depolarizing current pulses, delivered through the recording electrode, triggered trains of action potentials, while a constant depolarizing current produced evenly spaced action potentials in these cells, with very littlc adaptation during 5-10 min of current injection.

To explore whether the firing patterns of these cells were temperature-dependent (see Konishi and Kravitz, 1978), we tested responses over a range of temperatures from 6 to $16^{\circ} \mathrm{C}$. No significant change in resting potential or firing pattern was seen over this temperature range, although preparations survived longer if experiments were conducted at the lower temperatures.

Electrical coupling and direct synaptic interactions. No evi-

Note the similarity between the branching pattern of the HRP-injected cell (see the right-angle branch at arrow) and the photograph of the sertoninimmunoreactive branch of a $T 2$ ganglion shown in $D$. The HRP-filled fiber that projects out the ipsilateral thoracic second root of this ganglion is out of the focal plane of the photograph. The region of lateral ganglionic neuropil is labeled with an asterisk, in $4 C$. Scale bar, $165 \mu \mathrm{m}$. $D$, Photograph of part of a second thoracic ganglion stained immunocytochemically for scrotonin using a fluorescein-labeled secondary antibody. The midline of the ganglion is at the right margin of the picture. Note the right-angle branch (white arrow) that divides, sending 1 fiber laterally to form neuropil, and another fiber posteriolaterally out the thoracic second root. An identical pattern of immunoreactive staining is seen in the T1, T3, and T4. Black arrowhead points to 1 of the pair of serotonin-immunoreactive cells found in the second thoracic ganglion. Scale bar, $195 \mu \mathrm{m}$. (Reprinted with permission from Beltz and Kravitz, 1983). 

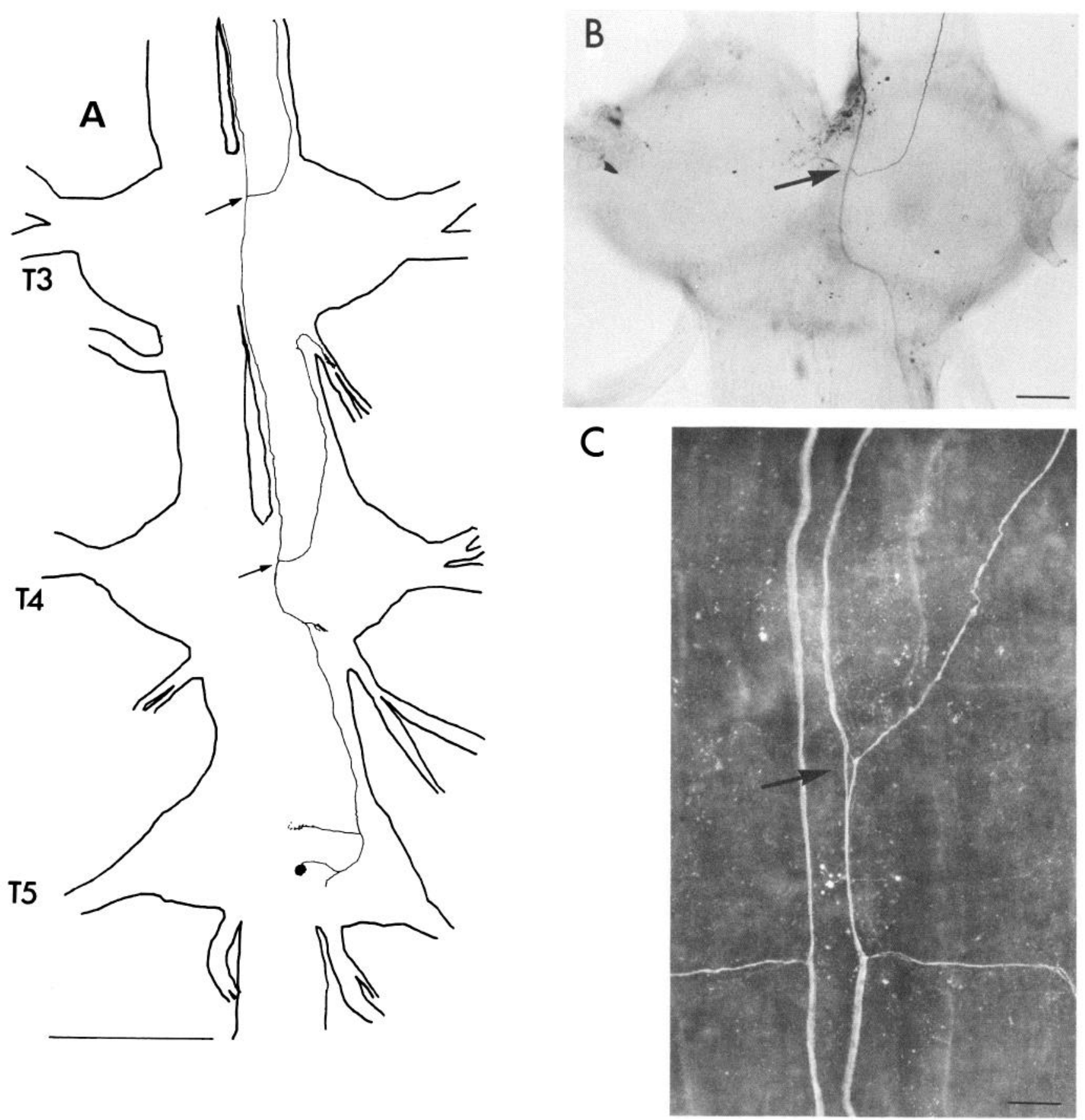

Figure 4. HRP injection of the right $T 5$ neuron and comparison of its branching pattern with fibers stained by serotonin immunocytochemistry. $A$, Computer reconstruction of a right $T 5$ cell and its projection. In $T 4$ and $T 3$ a fiber (arrows) branches off the main projection and travels anteriorly and laterally in the connective, finally going out the ipsilateral second root of the next anterior ganglion (shown here only for the branch formed in T4). This pattern of branches has also been seen in the second thoracic ganglion of other preparations (not shown). Scale bar, $1 \mathrm{~mm} . B$, Photograph of an anteriorly directed fiber branch (arrow) filled with HRP in a fourth thoracic ganglion (T4). A T5 serotonin-proctolin cell was injected with HRP to fill this process. The branch shown projects out the thoracic second root of the next anterior ganglion (T3). Compare with the immunocytochemical staining in $C$. Scale bar, $170 \mu \mathrm{m}$. $C$, Photograph of a third thoracic ganglion stained immunocytochemically for serotonin. Note the right-angle branch of the $A 1$ paired serotonin-proctolin neuron (see Fig. 3 and text) and the branch that projects anteriorly and laterally (arrow). In immunocytochemical preparations, the latter branch travels anteriorly in the connective and projects out the ipsilateral thoracic second root of the next anterior ganglion. Scale bar, $75 \mu \mathrm{m}$. $D$, Computer reconstruction of a right $T 5$ cell showing a different branching pattern than $A$. This HRP injection shows that the $T 5$ cell projects into the first thoracic $(T 1)$ ganglion. In each of the ganglia anterior to the cell body, a branch from the main fiber projects out the thoracic second root. This branch is formed in the same ganglion from which it projects, unlike the $T 5$ cell shown in $A$, where the branch travels into the next anterior ganglion before going out the second root. The cell-branching pattern shown here is similar to that shown in Fig. 3, $A-C$ for the $A l$ cell. Scale bar, $1.25 \mathrm{~mm}$. 


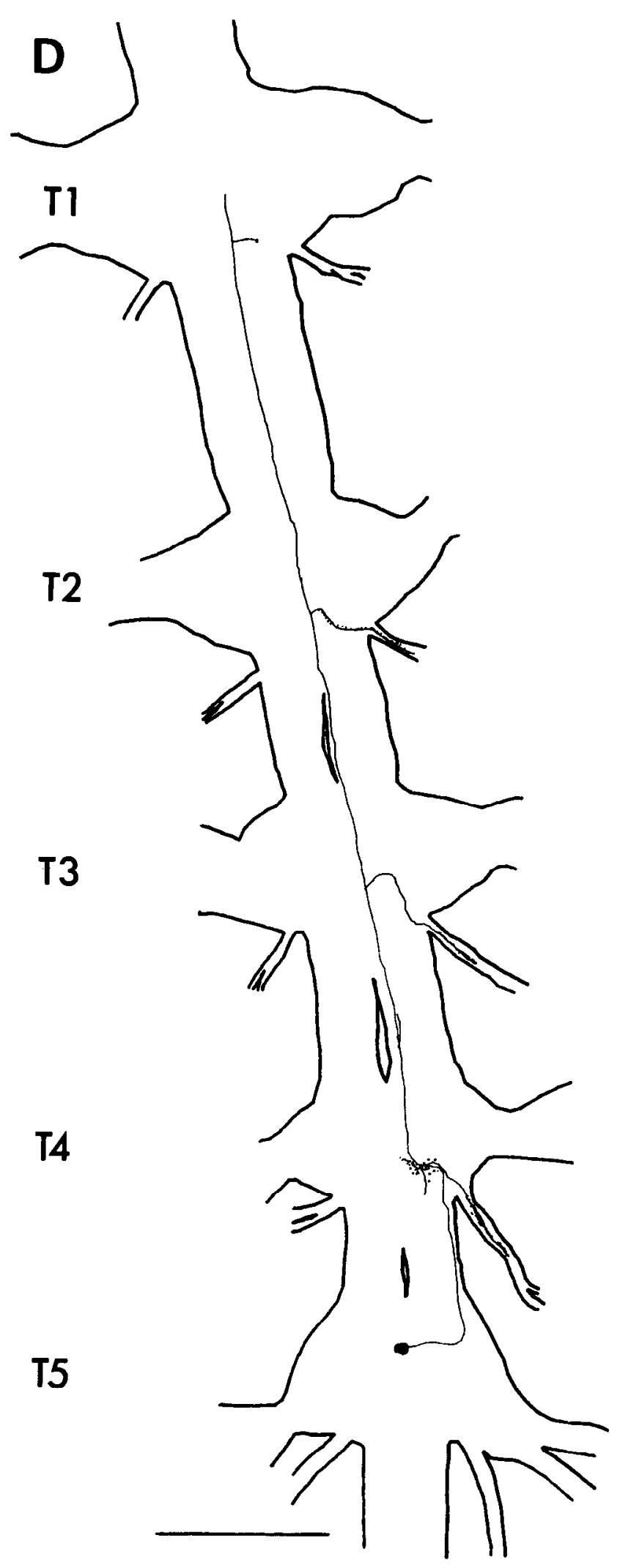

dence of electrical coupling was found with either hyperpolarizing or depolarizing pulses between pairs of cells in a single ganglion or between homologous cells in the T5 and Al ganglia. In addition, there was no evidence of direct synaptic connections between these cells.

\section{Anatomy of T5 and A1 serotonin-proctolin containing neurons}

To obtain a detailed picture of the neuronal geometry of these cells, we pressure-injected HRP into identified T5 and A1 cells (Figs. 3, $A-C ; 4, A, B, D$ ). Juvenile lobsters were used for these studies to maximize the likelihood that a major proportion of the dendritic and axonal arbors of each cell would be filled. The results showed that the T5 and A1 paired neurons were monopolar cells with very large fields of innervation projecting anteriorly through at least 5 segmental ganglia. In each thoracic ganglion a distinctive, repeating pattern of branches was seen (Figs. 3, $A-D$, and 4, $A-D$ ).

A1 serotonin-proctolin cells. A main trunk from the A1 cell body divides in the neuropil near the cell body sending a large (3-5 $\mu \mathrm{m})$ projection anteriorly and laterally in the ipsilateral connective (Fig. $3 A$ ). It and the other branch give rise to a multitude of fine, beaded fibers that traverse the hemiganglion in which the cell body was found (Fig. $3 B)$. A small $(1-2 \mu \mathrm{m})$ posteriorly directed process enters the posterior connective and appears to end as it emerges from the ganglion (Fig. $3 B$ ). In contrast, the anteriorly projecting process travels towards $\mathrm{T} 5$, sending branches out the second and third roots of $\mathrm{T} 5$ before it reaches the $\mathrm{T} 5$ ganglion, where it curves towards the midline and then turns sharply anteriorly, still in the ipsilaterial connective (Fig. 3A). From the earlier immunocytochemical studies, we know that at this point the process joins a medial bundle of serotonin containing fibers that run from the subesophageal ganglion (SG) to A6 (Fig. 3D). Immunocytochemical studies also showed that processes entering the second and third roots form a dense plexus of varicosities that cover the surface of the root. In the injected cells, some, but not many, varicosities in the roots were filled with HRP, presumably because diffusion limits access of the enzyme to the fine branches and varicosities. As the large midline projection travels forward and enters each anterior ganglion (T4, T3, T2), a right-angle fiber branches off the main axon, bifurcates and 1 branch travels out the second root of each ganglion (Figs. $3, A, C$, and $D$ ). This characteristic right-angle branch was seen in the thoracic ganglia from the SG to $\mathrm{T} 4$ in earlier immunocytochemical studies (Fig. $3 C$; Beltz and Kravitz, 1983), but at that time we did not know that the Al cells were the origin of these branches. A second branch from the right-angle process forms lateral neuropil regions in each of the anterior ganglia.

The T5 serotonin-proctolin cells. The projections of the T5 serotonin-proctolin-containing neurons are similar to those of the Al cells (Fig. 4, $A, D$ ); a large process from each T5 cell is directed anteriorly in a lateral fiber bundle for 1 segment (T5 to T4); then the process bends to the midline, where it joins the same fiber bundle as the projection from the ipsilateral A1 cell. The T5 cells also send branches out the second roots of anterior thoracic ganglia (T4, T3, T2, T1). There are 2 alternative routes that can be taken by these branches. From most $\mathrm{T} 5$ cells a fiber branches off the main projection in each thoracic ganglion and travels anteriorly to project out the second root of the next rostral ganglion (Fig. 4, $A, B$ ). This branch also had been seen, but not identified as to its origin in the earlier immunocytochemical studies (Fig. 4C). Alternatively, the branching pattern of some 


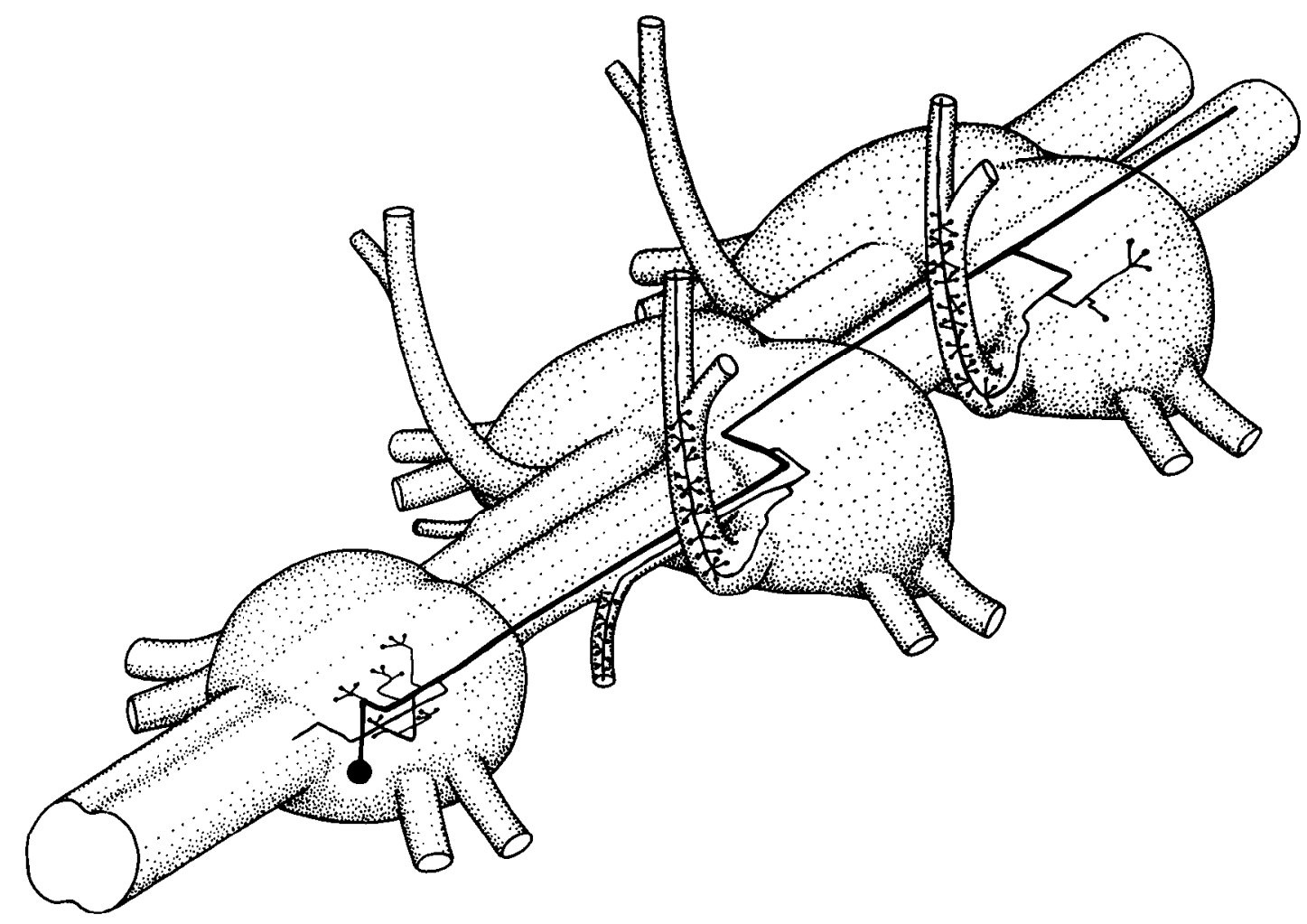

Figure 5. Composite drawing of the major features of a paired serotonin-proctolin neuron, illustrating the locations of the central and peripheral release sites. [Reprinted from Siwicki et al. (1985), with the permission of Peptides.]

T5 cells is similar to that of the Al cells (Fig. 4D). In these cases, a branch forms from the main fiber trunk and projects out the second root of the same ganglion (Fig. 4D). These branches usually do not form the geometric right-angle shapes that are formed by the Al cell branches; instead, the branch projects slightly anteriorly until it turns and is directed towards the second root (see T3, Fig. 4D). No cells have been seen that form both types of branches.

The projections of the $\mathrm{T} 5$ and $\mathrm{Al}$ pairs of cells into thoracic second roots account for all the presumptive serotonergic fibers originally found in these roots (Livingstone et al., 1981; Fig. 1 in Beltz and Kravitz, 1983). These cells, therefore, are the origin of the serotonergic peripheral root neurosecretory plexus. Immunocytochemistry also showed that a single fiber from either the T5 or A1 cells projects distally in the second roots towards the pericardial organs (Beltz and Kravitz, 1983).

Our analysis of the T5 and Al cells is limited by the distance that HRP diffuses in these tissues $(2-3 \mathrm{~cm})$. In each case, however, the most distal HRP-filled process fades out in each injected cell rather than ending abruptly or forming terminal arborizations, as might be expected if the cells were completely filled. Immunocytochemical studies, particularly in larval lobsters, show processes of similar morphology to the identified T5 and Al cell branches in the subesophageal ganglion. These neurons, therefore, have enormous arbors of endings, possibly projecting all the way to the SG. In addition, the immunocytochemical and anatomical data suggest that these cells are likely to release their transmitter contents both into the peripheral circulation from the thoracic second root neurosecretory regions and into central neuropil regions in the thoracic ganglia (Fig. 5).

\section{Embryonic and larval studies: development of transmitter phenotypes in $T 5$ and Al neurons}

Embryonic lobsters develop in eggs that are attached to the mother's swimmerets on the ventral side of the abdomen. Normally, the females extrude and fertilize the eggs during September or October, then brood them under the abdomen until the following May or June, when all the larvae hatch within a few days of one another (Herrick, 1896). Development is not constant during this period, however. After extrusion, development proceeds for several months until the water temperature falls below about $8^{\circ} \mathrm{C}$. Below that temperature, development slows dramatically or stops. In New England waters, therefore, there normally is little development of Homarus eggs from December through April. Since the rate of embryonic development is variable and temperature-dependent, exact developmental stages cannot be determined simply from knowledge of the time of fertilization. Instead, an eye-size index is used in conjunction with time of fertilization (if known) and eventual time of hatching of the brood to stage embryos (see Materials and Methods). The embryonic data presented here come from animals with eye indices of 320-360 units, representing animals approximately 4-5 months from hatching. Such embryos were about halfway through development by these criteria, and were taken from mothers during the dormant period of the winter months in New England waters.

It was of interest to see when in development serotonin and proctolin immunostaining appeared in the $\mathrm{T} 5$ and $\mathrm{A} 1$ cells. Therefore, immunocytochemical studies were carried out with ventral nerve cords from mid-stage embryos (see Materials and Methods and above) and from the first 4 larval stages of lobsters 
(see Materials and Methods). These studies demonstrated that even midstage embryos show a system of neurons and neuronal processes staining for serotonin, similar in its main features to that seen in adults (Fig. 6, $A$ and $B$ ). All of the approximately 100 presumptive serotonergic neurons can be accounted for, and their positions and relative sizes are typical of the same neurons in the adult lobster. In contrast to the early appearance of serotonin immunoreactivity, however, proctolin staining (scen in about 1500 neurons in juvenile lobsters; see Siwicki and Bishop, 1986) is observed in only a few hundred anteriorly located cell bodies in embryos (with 1 exception; see below and Fig. $6 C$ ). Staining appears in the remaining neurons during late embryonic and early larval development (Fig. 7C).

Although we do not know precisely when serotonin immunoreactivity first appears in the T5 and A1 serotonin-proctolin neurons, these cells do show serotonin immunoreactivity in midstage embryos (Fig. 6, B, D). The characteristic branch points of these cells also are well developed (see Figs. 3 and 4), as are the plexuses of varicosities in the proximal regions of the thoracic second roots (see Figs. 1 and 5). In contrast, proctolin-like immunostaining is not seen in the $\mathrm{T} 5$ and $\mathrm{A} 1$ neurons at this developmental stage (Fig. 6, $C, E$ ). Proctolin-like immunoreactivity is seen first in these cells in embryos just prior to hatching, and staining intensity increases in larvae until about the fourth stage, when the density of staining is similar to that seen in juveniles (see Fig. $7 C$ and Siwicki and Bishop, 1986). Staining of neuropil branches of the T5 and Al cells for proctolin appears even later, and is probably not complete until the sixth larval stage. Also shown in Fig. 6, $C$ and $E$, is a single large midline cell staining for proctolin in the second abdominal ganglion. This cell stains for proctolin only in embryonic and early larval life and either loses the proctolin immunoreactivity or dies.

\section{Discussion}

The premise with which this paper began was that amines and peptides are likely to play vital roles in regulating or controlling behavior. Some steps we are following in attempting to define these roles are (1) to identify the parts of the behavioral repertoire where amines or peptides might play a role; (2) to study how exogenous amines and peptides might act on the nervous system to produce these effects; (3) to find identifiable neurons containing these substances; (4) to develop methods for recording from such neurons, both to learn how the cells are normally activated and to explore the consequences of their activation; and (5) to try to fit the circuitry with which these neurons interact and the type of interaction back into the picce of behavior under investigation. In lobsters, injection of the amines serotonin and octopamine trigger opposing postures that resemble "aggressive" and "submissive" stances seen during normal behavior in these animals (Scrivener, 1971; Atema and Cobb, 1980; Livingstone et al., 1980). Physiological studies demonstrated that exogenous amines triggered these opposing postures by actions both in the ventral nerve cord, where specific motor programs were activated, and on exoskeletal muscles, where the tissues were primed to respond more vigorously (Livingstone et al., 1980; Harris-Warrick and Kravitz, 1984). The search for identified neurons that might contain these amines has focused on serotonin thus far, and has narrowed to the 2 pairs of neurons that are the subject of this paper, the 2 pairs of cells in the fifth thoracic (T5) and first abdominal (A1) ganglia (Beltz and Kravitz, 1983; Siwicki et al., 1987). These cells were chosen for investigation because immunocytochemical studies indicated that they had both central and peripheral projections (Beltz and Kravitz, 1983), projections that might account for the central and peripheral actions of serotonin. The morphological, physiological, and developmental studies presented in this paper, and the biochemical results of the preceding paper (Siwicki et al., 1987) demonstrate that the T5 and A1 paired cells have several interesting and useful features. They can reliably be found and recorded by using size, position, and physiological properties as criteria for identification. They have enormous fields of innervation projecting in an anterior direction into at least the next 4 segmental ganglia (possibly all the way to the subesophageal ganglion) and arborizing in a repetitive fashion in the neuropil regions of each ganglion. They are the origin of the neurosecretory plexuses that supply serotonin to the hemolymph through branches sent into the second roots of each thoracic ganglion, which then ramify into superficial varicosities. They are usually spontaneously active cells that show large overshooting action potentials in their cell bodies. In addition to containing serotonin, these cells also contain the peptide proctolin (Siwicki et al., 1987) and both substances have actions on motor programs (Livingstone et al., 1980; Bradbury and Mulloney, 1982; Hooper and Marder, 1984, 1985). Finally, immunostaining for serotonin and proctolin appears in these cells at widely different times in development.

Some of the above points require further comment. Large fields of innervation are a general feature of amine neurons in both vertebrate and invertebrate nervous systems (Pentreath et al., 1973; Parent, 1981; Parent et al., 1981). In this respect the T5 and A1 neurons are typical amine cells. On the other hand, while the fields of innervation of these cells are large, they are not random. The cells have 2 distinct sets of endings. A peripheral set along the thoracic second roots has the morphological features of neurosecretory terminals (Livingstone et al., 1981) and is a likely source of serotonin (and possibly proctolin) for actions on exoskeletal muscles. A central set is associated with a highly repetitive set of branches of these cells, given off as their processes ascend through more anterior thoracic ganglia. The central endings might mediate the central actions of serotonin on motor programs. The T5 and Al neurons, however, do not seem to function as "command neurons" (single cells whose activation leads to the triggering of a complex pattern of behavior like a motor program) (Evoy and Kennedy, 1967; Kennedy et al., 1967; Larimer et al., 1986). In preliminary experiments, it appears that these cells are influenced by "command neurons" in appropriate ways to play some role in the "command neuron" circuitry, but precisely how they function and what their targets are within the neuropil of central ganglia remains to be elaborated (B. S. Beltz and E. A. Kravitz, unpublished observations). These topics are the focus of our present physiological studies.

The $\mathrm{T} 5$ and $\mathrm{A} 1$ cells project their axonal arbors in an anterior direction, into the thoracic parts of the animal. Few, if any, processes travel into more posterior abdominal ganglia. When amines are injected into animals, however, postural changes are seen in both thoracic and abdominal regions. Close examination of the morphological features of ventral nerve cords from juvenile, larval, and embryonic animals (Beltz and Kravitz, 1983, and unpublished observations) processed immunocytochemically for serotonin, suggest that the T5 and Al cells may be part of a set of neurons, 1 pair of which is found in each abdominal ganglion. The $\mathrm{T} 5$ and $\mathrm{A} 1$ cells are more than twice as large as 


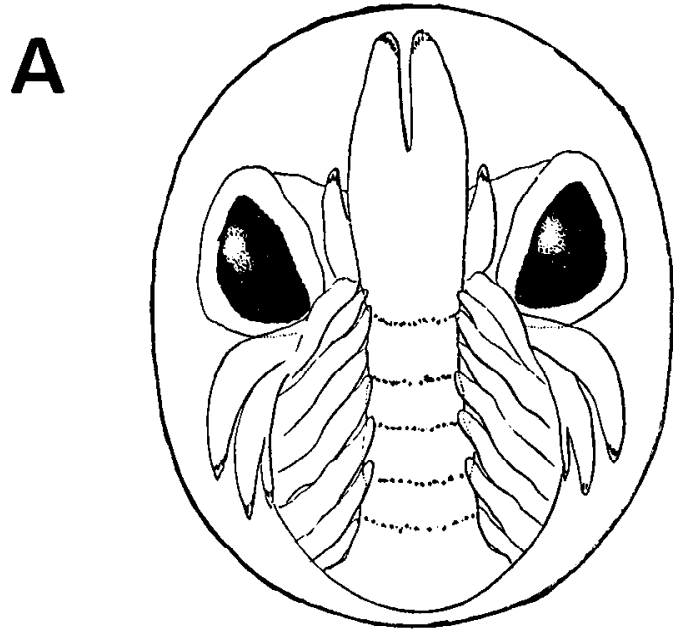

B

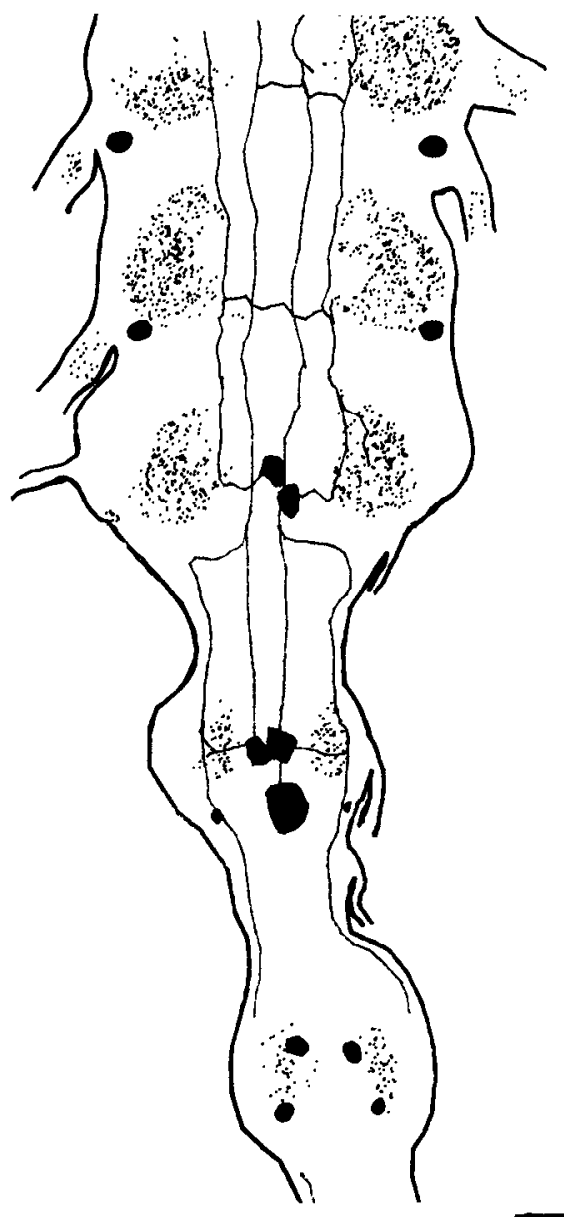

T3

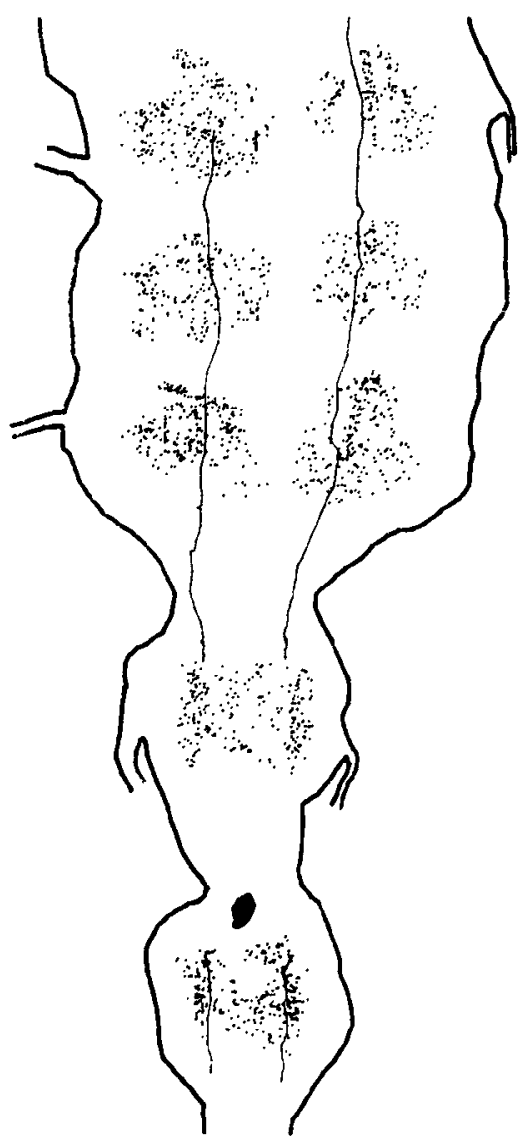

Figure 6. A, A drawing from Herrick (1896) illustrating the general appearance of the embryos used for the studies in $B$ and $C$. Note that the tail is folded ventrally, so that it is situated between the eyes. $\times 25$. $B$, Embryonic nerve cord (eye index, 325) stained immunocytochemically for serotonin. Shown here are the third (T3), fourth (T4), and fifth (T5) thoracic ganglia and first $(A I)$ and second $(A 2)$ abdominal ganglia. The staining pattern can be compared with the adult pattern shown in Figure 1 . Note that the paired neurons in $T 3-T 5$ and $A 1$ already stain for serotonin at this embryonic stage, as does the unpaired medial cell in $A 1$. Neuropil (stippled area) and fibers reminiscent of the adult pattern also stain in these midstage embryos, although the full complement of adult fibers is not apparent until later in embryonic life. Scale bar, $500 \mu \mathrm{m}$. $C$, Embryonic nerve cord (eye index, 360) stained immunocytochemically for proctolin. $T 3-T 5, A 1$ and $A 2$ ganglia are shown. Although some fibers and neuropil are stained, only 1 cell body-an unpaired anterior medial cell in $A 2$-shows proctolin immunoreactivity in this part of the nervous system. The full complement of proctolin-immunoreactive cell bodies seen in adult preparations is not seen in development until the fourth or fifth larval stage (see Fig. 7, larval stage 3, and Siwicki and Bishop, 1986). Scale, same as $B$. $D$ and $E$, Whole mounts of the $T 5, A 1$, and $A 2$ ganglia of lobsters approximately halfway through embryonic development stained for $(D)$ serotonin- and $(E)$ proctolin-like immunoreactivities. At this stage, the identified $T 5$ and $A I$ cell pairs stain for serotonin (arrows in $D$ ), but do not stain with antibody to proctolin $(E)$, even though other proctolin- 
the other members of the set, but in each abdominal ganglion (A2-A6), a pair of serotonin-immunoreactive neurons is found, which sends an axon forward in a lateral fiber bundle. The axon turns towards the midline just before the next anterior ganglion. The fibers then join the same midline bundle to which the T5 and A1 neurons will ultimately project, and give off a small spray of neuropil branches in 1 or more anterior ganglia (Beltz and Kravitz, 1983). It remains possible that for a coordinated role of serotonin in postural control, the entire set of 14 neurons must be activated, a possibility we are currently exploring. We also do not know yet whether proctolin is colocalized with serotonin in the posterior 10 cells of this set.

The large action potentials and spontaneous activity seen in the T5 and A1 cells are not typical of most neurons in lobster ventral nerve cords (Otsuka et al., 1967; Thompson and Page, 1982). Action potential size recorded in cell bodies is usually 5-10 $\mathrm{mV}$ and, with only few exceptions, the cells are silent. The activity seen in the serotonin-proctolin cells has been seen in other lobster neurohormonal cells, however (Konishi and Kravitz, 1978).

The developmental studies raise several interesting questions.
First, if the T5 and A1 neurons are concerned mainly with postural mechanisms, why are the arbors of these neurons so well formed, and why do they express serotonin so early in development? Many of the postural muscles that we believe are under modulatory control by serotonin in adult animals do not even exist at the time that a plexus of neurosecretory endings containing serotonin is found on thoracic second roots. When do the circuitries involving flexor and extensor motor programs first develop, and when do they first become sensitive to serotonin? It is also of considerable interest that serotonin and proctolin immunostaining appears at such widely different times in development in the T5 and A1 neurons. Serotonin staining is seen early in development, possibly at the time of the terminal differentiation of the cells (Lauder et al., 1982; Taghert and Goodman, 1984), while proctolin staining first appears at close to the time of hatching, probably some 4-6 months later in the wild. Proctolin staining is not complete until between the fourth and sixth larval stages, another several weeks after staining is first seen. Thus proctolin staining is increasing during a period of dramatic metamorphosis of larval lobsters, the transition from first-stage animals that do not look or behave like mature

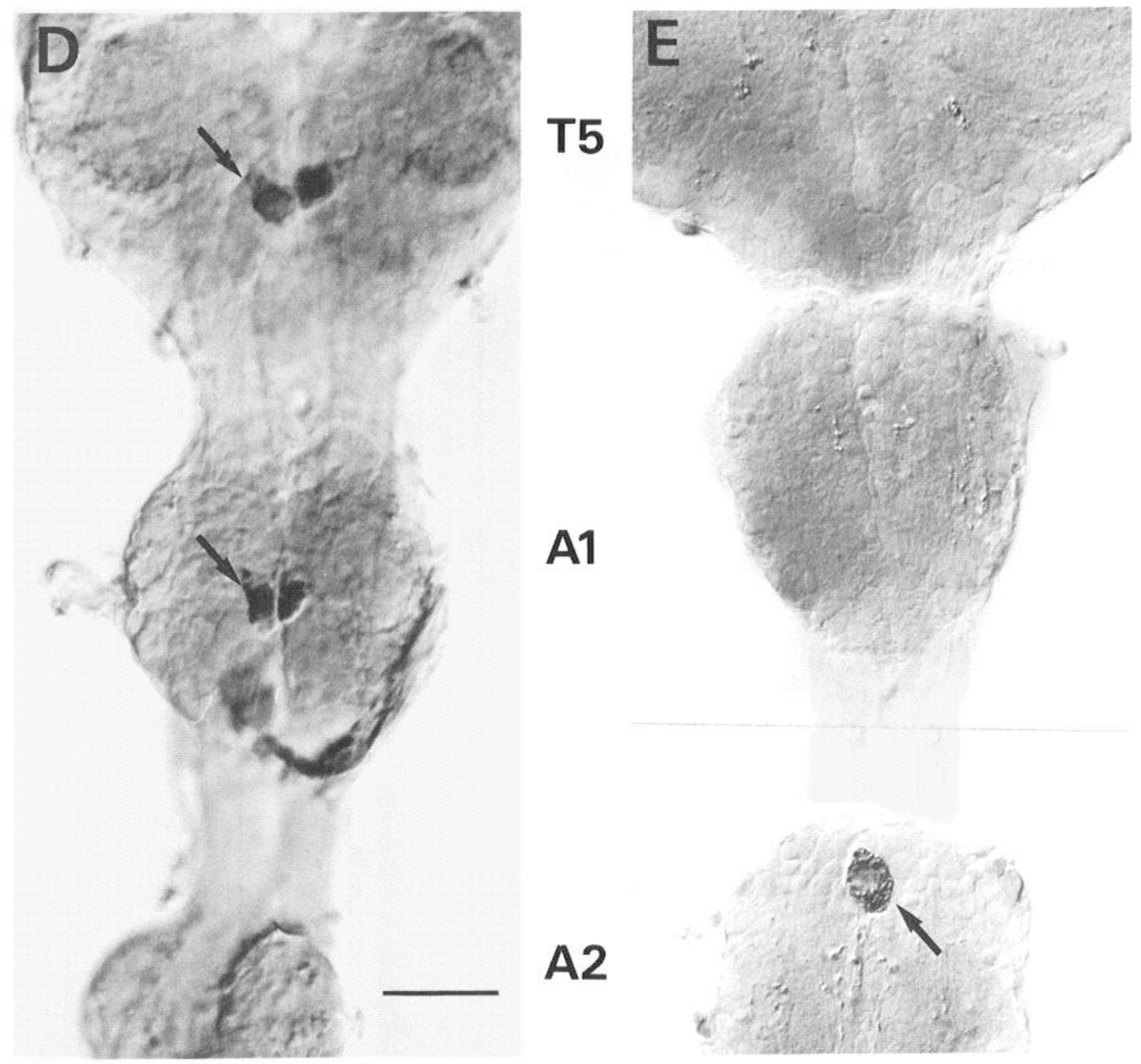

positive cells are present (see unpaired stained cell at arrow in $A 2$ and text). Proctolin-like staining first appears in the $T 5$ and $A 1$ cells in late embryonic and early larval stages. Scale bar, $50 \mu \mathrm{m}$. ( $D$ and $E$ Reprinted with permission from Siwicki et al., 1985.) 
B

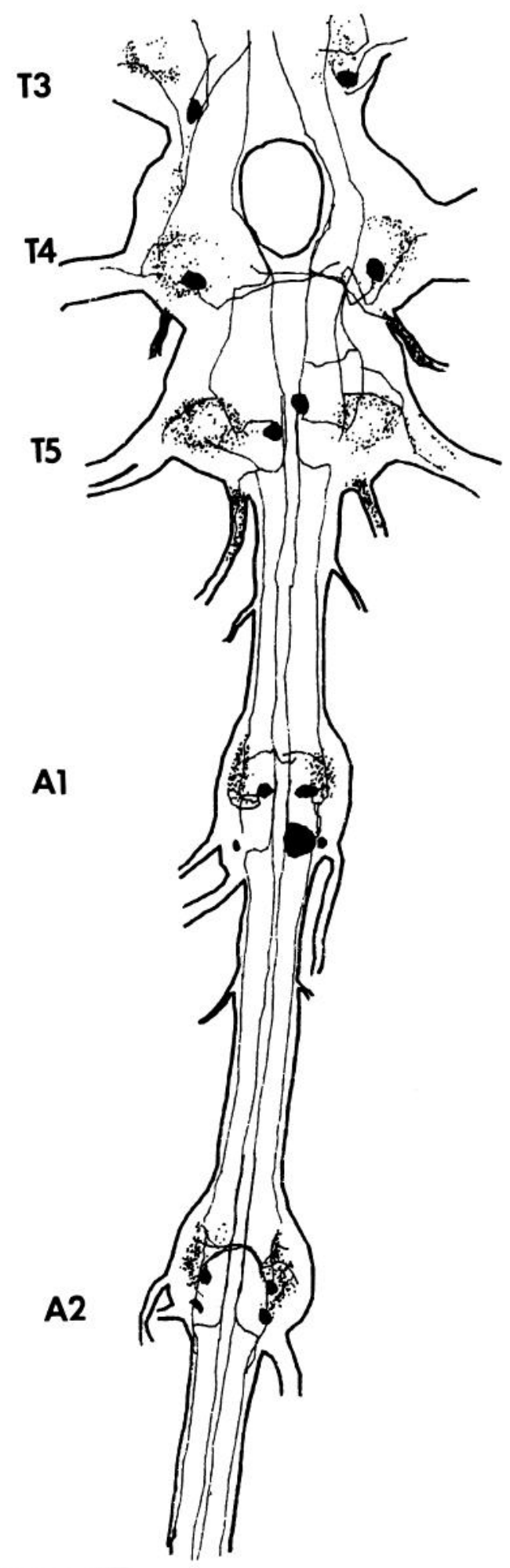

A

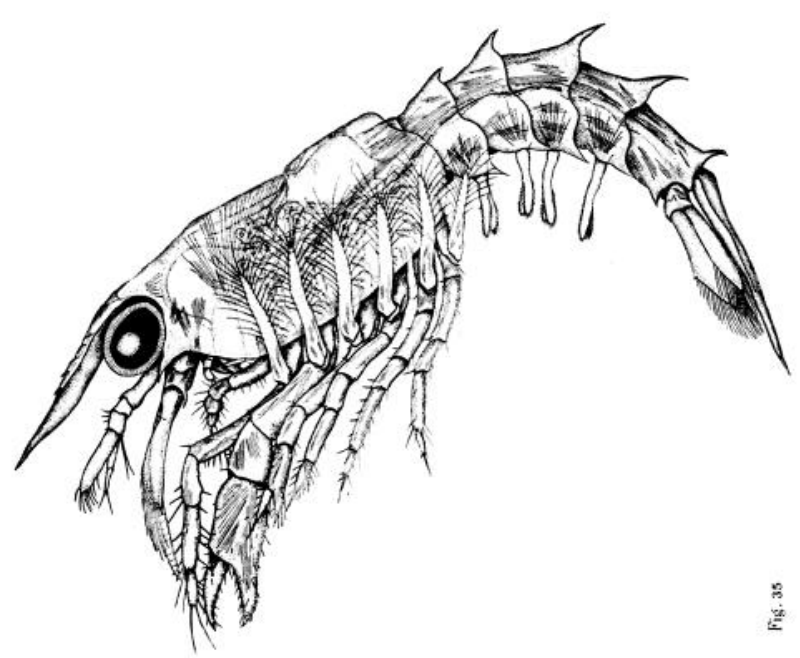

C

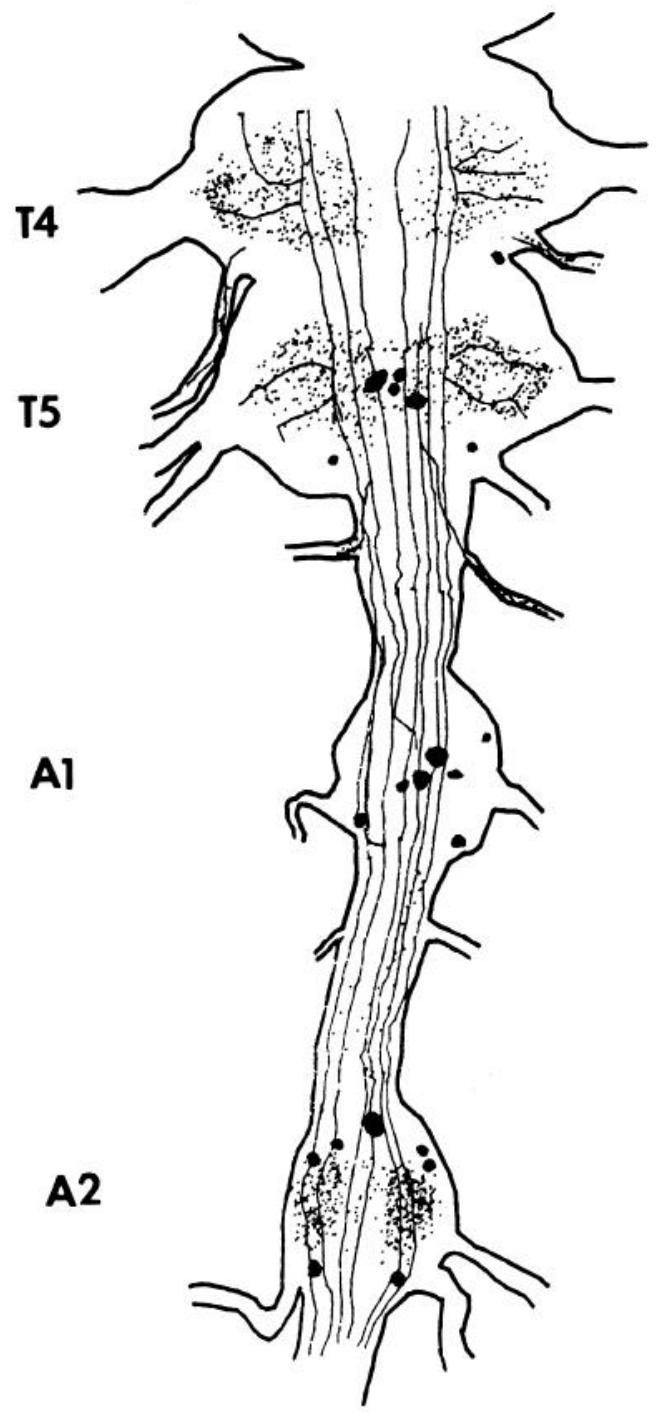

Figure 7. A, Drawing from Herrick (1896) showing the external appearance of a third-stage larva (lateral view). The major features noticeable at this stage are growth and development of the large claws, and the acquisition of the last pair of abdominal appendages which, with the telson, compose the tail fan. $\times 10 . B$, Serotonin immunoreactivity in a portion $(T 3-A 2)$ of a third-stage larva. Stained cell bodies, fibers, and neuropil regions (stippled areas) are basically organized as they are in the adult nervous system. Scale bar, $250 \mu \mathrm{m}$. $C$, Proctolin immunoreactivity in a portion $(T 4-A 2)$ of a third-stage larva. Note that the number of stained neurons and fibers has increased dramatically since midembryonic life (see Fig. $6 C$ ). The $T 5$ and $A 1$ paired serotonin-proctolin neurons are apparent at this stage, although they stain more darkly in later larval stages. (To compare with adult staining pattern, see Siwicki and Bishop, 1986.) Same scale as $B$. 
lobsters to fourth-stage animals that resemble miniature lobsters. Immunostaining cannot tell whether proctolin first appears in these neurons at late developmental stages, or whether this is only a time of a rapid increase in proctolin content from low immunocytochemically undetectable levels to levels observable with our antibodies. Molecular genetic studies searching for the time of first appearance of the mRNA coding for a proctolin precursor would be much better in this regard. At present, we are attempting to develop probes suitable for this purpose. If molecular genetic studies confirm that the serotonin and proctolin phenotypes are regulated independently, this may be a useful system for studying the function of the same amine cells before and after they express their peptide function, and to examine the factors that regulate this expression.

In exploring the linkage between serotonin and proctolin and aspects of lobster behavior, then, we have observed postural effects of amine injection that can be linked to "aggressive" behavior, we have some understanding of how exogenous amines exert thcse cffects, and we have found individual serotoninproctolin-containing cells that may play some role in these postural controls. Further studies will be required to define these roles more fully and, ultimately, to link activation of such cells to the behaviors under examination.

\section{References}

Atema, J., and J. S. Cobb (1980) Social behavior of lobsters. In The Biology and Management of Lobsters, vol. 1, Physiology and Behavior, J. S. Cobb and B. F. Phillips, eds., Academic, New York.

Beltz, B. S., and E. A. Kravitz (1983) Mapping of serotonin-like immunoreactivity in the lobster nervous system. J. Neurosci. 3: 585602 .

Bradbury, A. G., and B. Mulloney (1982) Proctolin activates and octopamine inhibits swimmerets beating. Soc. Neurosci. Abstr. 8: 736.

Capowski, J. J., and M. J. Sedivec (1981) Accurate computer reconstruction and graphics display of complex neurons utilizing state-ofthe-art interactive techniques. Comput. Biomed. Res. 14: 518-532.

Evans, P. D., E. A. Kravitz, B. R. Talamo, and B. G. Wallace (1976) The association of octopamine with specific neurons along lobster nerve trunks. J. Physiol. (Lond.) 262: 51-70.

Evoy, W. H., and D. Kennedy (1967) The central nervous organization underlying control of antagonistic muscles in the crayfish. I. Types of command fibers. J. Exp. Zool. 165: 223-238.

Flamm, R. E., and R. M. Harris-Warrick (1986a) Aminergic modulation: I. Effects on the motor pattern and activity of neurons within the pyloric circuit. J. Neurophysiol. 55: 847-865.

Flamm, R. E., and R. M. Harris-Warrick (1986b) Aminergic modulation in the lobster stomatogastric ganglion: II. Target neurons of dopamine, octopamine, and serotonin within the pyloric circuit. J. Neurophysiol. 55: 866-881.

Harris-Warrick, R. (1985) Amine modulation of extension command element-evoked motor activity in the lobster abdomen. J. Comp. Physiol. 156: 875-884.

Harris-Warrick, K., and E. A. Kravitz (1984) Cellular mechanisms for modulation of posture by octopamine and serotonin in the lobster. J. Neurosci. 34: 1976-1993.

Herrick, F. H. (1896) The American lobster: A study of its habits and development. Bull. US Fish Commission 15: 1-252.

Hooper, S. L., and E. Marder (1984) Modulation of a central pattern generator by two neuropeptides, proctolin and FMRFamide. Brain Res. 305: 186-191.

Hooper, S. L., and E. Marder (1985) Neuronal targets of the modulatory action of proctolin on the pyloric system of the stomatogastric ganglion of Panulirus irroratus. Soc. Neurosci. Abstr. 11: 478.

Kennedy, D., W. H. Evoy, B. Dane, and J. T. Hanawalt (1967) The central nervous organization underlying control of antagonistic muscles in the crayfish. II. Coding of position by command fibers. J. Exp. Zool. 165: 239-248.

Konishi, S., and E. A. Kravitz (1978) The physiological properties of amine-containing neurones in the lobster nervous system. J. Physiol. (Lond.) 279: 215-229.

Kravitz, E. A., B. Beltz, S. Glusman, M. Goy, R. Harris-Warrick, M. Johnston, M. Livingstone, T. Schwarz, and K. K. Siwicki (1985) The well-modulated lobster: The roles of serotonin, octopamine, and proctolin in the lobster nervous system. In Model Neural Networks and Behavior, A. Selverston, ed., pp. 339-360, Plenum, New York.

Kristan, W. B., and M. P. Nusbaum (1983) The dual role of serotonin in leech swimming. J. Physiol. (Paris) 78: 743-747.

Kristan, W. B., and J. C. Weeks (1983) Neurons controlling the initiation, generation, and modulation of leech swimming. Soc. Exp. Biol. Symp. 37: 243-260.

Kuhlman, J. R., C. Li, and R. L. Calabrese (1985a) FMRF-amidelike substances in the leech. I. Immunocytochemical localization. J. Neurosci. 5: 2301-2309.

Kuhlman, J. R., C. Li, and R. L. Calabrese (1985b) FMRF-amidelike substances in the leech. II. Bioactivity on the heartbeat system. J. Neurosci. 5: 2310-2317.

Kupfermann, I. (1967) Stimulation of egg laying: Possible neuroendocrine function of bag cells of abdominal ganglion of Aplysia californica. Nature (Lond.) 216: 814-815.

Kuramoto, T., and A. Ebara (1984) Neurohormonal modulation of the cardiac outflow through the cardioarterial valve in the lobster. $\mathrm{J}$. Exp. Biol. 111: 123-130.

Larimer, J. L., J. Jellies, and D. Moore (1986) The crayfish position on command neurons. Bchav. Brain Sci. (in press).

Lauder, J. M., P. Petrusz, J. A. Wallace, A. Dinome, M. B. Wilkie, and K. McCarthy (1982) Combined serotonin immunocytochemistry and $3 \mathrm{H}$-thymidine autoradiography: In vivo and in vitro methods. J. Histochem. Cytochem. 30: 788-793.

Lent, C. M., and M. H. Dickinson (1984) Serotonin integrates the feeding behavior of the medicinal leech. J. Comp. Physiol. 154: 457471.

Lingle, C. (1981) The modulatory action of dopamine on crustacean foregut neuromuscular preparations. J. Exp. Biol. 94: 285-299.

Livingstone, M. S., R. M. Harris-Warrick, and, E. A. Kravitz (1980) Serotonin and octopamine produce opposite postures in lobsters. Science $208: 76-78$.

Livingstone, M. S., S. F. Schaeffer, and E. A. Kravitz (1981) Biochemistry and ultrastructure of serotonergic nerve endings in the lobster: Serotonin and octopamine are contained in different nerve endings. J. Neurobiol. 12: 27-54.

Mayeri, E., and B. S. Rothman (1985) Neuropeptides and the control of egg-laying behavior in Aplysia. In Model Neural Networks and Behavior, A. I. Selverston, ed., pp. 285-302, Plenum, New York.

O'Donohue, T. L., J. F. Bishop, B. M. Chronwall, J. Groome, and W. H. Watson III (1984) Characterization and distribution of FMRFamide immunoreactivity in the rat central nervous system. Peptides 5: 563-568.

Otsuka, M., E. A. Kravitz, and D. D. Potter (1967) Physiological and chemical architecture of a lobster ganglion with particular reference to gamma-aminobutyrate and glutamate. J. Neurophysiol. 30: 725752.

Parent, A. (1981) The anatomy of serotonin containing neurons across phylogeny. In Serotonin Neurotransmission and Behavior, B. L. Jacobs and A. Gelperin, eds., pp. 3-34, MIT, Cambridge, MA.

Parent, A., L. Descarries, and A. Beaudet (1981) Organization of ascending serotonin systems in the adult rat brain. A radioautographic study after intraventricular administration of $[3 \mathrm{H}] 5 \mathrm{HT}$. Neuroscience 6: 115-138.

Pentreath, V. W., N. N. Osborne, and G. A. Cottrell (1973) Anatomy of giant serotonin-containing neurons in the cerebral ganglia of Helix pomatia and Limax maximus. Z. Zellforsch. Mikroskop. Anat. 143: $1-20$.

Perkins, H. C. (1972) Developmental rates at various temperatures of embryos of the northern lobster (Homarus americanus Milne-Edwards). Fishery Bull. 70: 95-99.

Reynolds, S. E., and J. W. Truman (1983) Eclosion hormone. In Endocrinology of Insects, R. G. H. Downer and H. Saufer, eds., pp. 217-233, Alan R. Liss, New York.

Scrivener, J. C. E. (1971) Agonistic behavior of the American lobster Homarus americanus (Milne-Edwards). Technical report 235, pp. 1114, Fisheries Research Board of Canada.

Siwicki, K. K., and C. A. Bishop (1986) Mapping of proctolin-like 
immunoreactivity in the nervous systems of lobster and crayfish. J. Comp. Neurol. 243: 435-453.

Siwicki, K. K., B. S. Beltz, T. L. Schwarz, and E. A. Kravitz (1985) Proctolin in the lobster nervous system. Peptides 6 (Suppl. 3): 393402.

Siwicki, K. K., B. S. Beltz, and E. A. Kravitz (1987) Proctolin in identified serotonergic, dopaminergic, and cholinergic neurons in the lobster, Homarus americanus. J. Neurosci. 7: 522-532.

Stewart, W. W. (1978) Functional connections between cells as revealed by dye-coupling with a highly fluorescent naphthalimide tracer. Cell 14: 741-759.

Strumwasser, F. (1983) Peptidergic neurons and neuroactive peptides in molluscs: From behavior to genes. In Brain Peptides, D. T. Krieger, M. J. Brownstein, and J. B. Martin, eds., pp. 183-215, Wiley, New York.
Taghert, P. H., and C. S. Goodman (1984) Cell determination and differentiation of identified serotonin-immunoreactive neurons in the grasshopper embryo. J. Neurosci. 4: 989-1000.

Thompson, C. S., and C. H. Page (1982) Command fiber activation of superficial flexor motoneurons in the lobster abdomen. J. Comp. Physiol. 148: 515-527.

Truman, J. W., and J. C. Weeks (1985) Activation of neuronal circuits by circulating hormones in insects. In Model Neural Networks and Behavior, A. I. Selverston, ed., pp. 381-400, Plenum, New York.

Willard, A. L. (1981) Effects of serotonin on the generation of the motor program for swimming by the medicinal leech. J. Neurosci. 1: 936-944. 